\title{
New range extensions for the Canadian Chironomidae fauna from two urban streams
}

\author{
Armin Namayandeh*1 and David V. Beresford ${ }^{3}$ \\ ${ }^{1}$ Taxanama Corp. 25 Mabelle Ave, Toronto, ON, M9A 4Y1, E-mail: a.namayan@taxanama.com. \\ ${ }^{3}$ Department of Biology, Trent University, Peterborough, Ontario, E-mail: davidberesford@trentu.ca. \\ *Corresponding author.
}

\begin{abstract}
We report on 2 first records of Chironomidae for Ontario, Rheosmittia spinicornis (Brundin, 1956) and Sublettea coffmani (Roback 1975), and confirm a previous record of Odontomesa fulva (Kieffer 1919) from Ontario. Specimens of $S$. coffmani have been only reported from New Brunswick whereas R. spinicornis has records from northern, western and central provinces and territories. Reports of $O$. fulva were not confirmed in Ontario. Here we report its occurrence for the second time in south central Ontario, confirming its occurrence within the province.
\end{abstract}

\section{Introduction}

The range of a species is the fundamental unit of biogeography. New records give us insights into how changing land use and climate alters the distribution of species. The taxa from urban and suburban streams are typically well-studied and well-known. As a result, these areas are often overlooked as potential sites to look for new range records. In this paper, we use data obtained during the Central Lake Ontario Conservation Authority's biomonitoring program in 2017 from urban and suburban streams. We report on new range records of Chironomidae, including 2 first provincial records for the province of Ontario.

\section{Study area and methods}

Specimens were collected from Bowmanville Creek in Bowmanville and Lynde Creek in Whitby, Ontario, Canada as part of Central Lakes Ontario Conservation Authority's biomonitoring program from March-August 2017. Bowmanville Creek, Lynde Creek and their tributaries are located within the Regional Municipality of Durham. The watershed of Lynde Creek passes through the Township of Uxbridge, Township of Scugog, City of Pickering, Town of Ajax, and the Town of Whitby in Ontario, Canada. The urban area of the Town of Bowmanville occupies the south part of the Bowmanville watershed and the mid-to-northern part of the watershed are in agricultural lands. Lynde Creek and its tributaries drain an area of approximately 130 $\mathrm{km}^{2}$. The Bowmanville/Soper Creek Watershed drain an area of approximately $170 \mathrm{~km}^{2}$. The headwaters of both waters originate in the Oak Ridges Moraine, an ecologically important area in southcentral Ontario. Lynde Creek drains into Lake Ontario through Lynde Creek Marsh and Bowmanville drains into Lake Ontario through the Bowmanville Coastal Wetland Complex, a provincially significant wetland (Central Lake Ontario Conservation 2012, 2013).

Samples were collected, sorted, and stored using Ontario Benthos Biomonitoring Network standard methods (Jones et al. 2007). Specimens of immatures and adults were mounted following methods described by Epler (2001) and Pinder (1978) and images were obtained using an OMAX A3550U Camera mounted on AMScope compound microscope. All abbreviations follow Sæther (1980). Voucher specimens were submitted to the Canadian National Collection of Insects, Arachnids and Nematodes (CNC) in Ottawa, Canada.

\section{Results}

Odontomesa fulva (Kieffer, 1919)

Larva (n=2). Figs. 1a-g.

Description. Postmentum $\mathrm{L}=184.3-202.5 \mu \mathrm{m}(194.3 \mu \mathrm{m})$. Antenna 4 segmented (Fig. 1a), AR=2.0-2.4 (2.2). Labrum with S IV A and premandibles (Fig. 1b). Mentum (Fig. 1c). Posterior margin of ventromental plates more or less straight and parallel with anterior margin (Fig. 1d). Mandible with seta interna split into 3 segments (Fig. 1e); basal external seta of mandible splits into 2-8 setae from the base (Fig. 1e-f). Procercus well-sclerotized with 8 apical setae. 2 long anal setae are present (Fig. 1g). Posterior parapods $3 \mathrm{X}$ longer than wide (Fig. 1g). Four cone shaped anal tubules are present (Fig. 1g). 

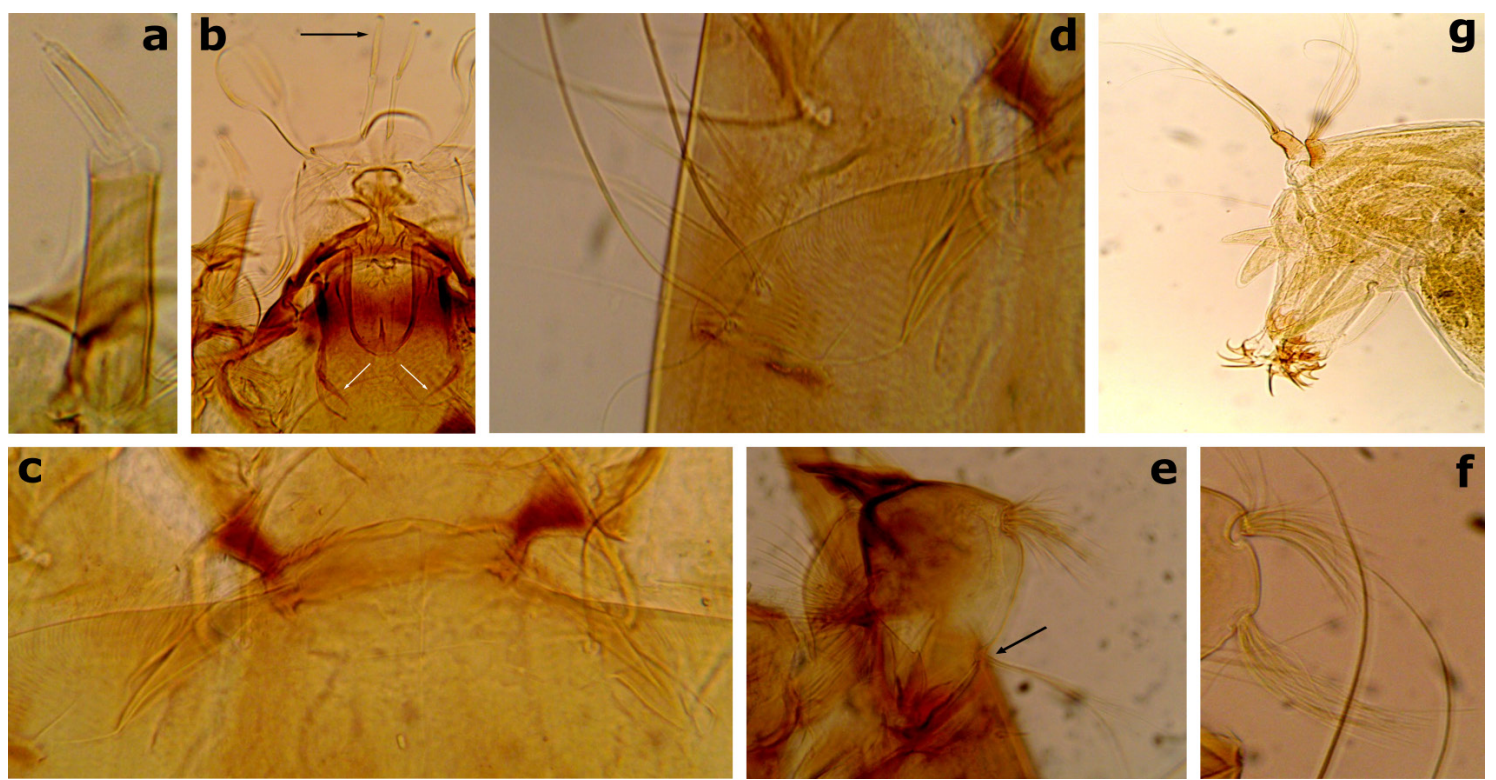

Figure 1. Odontomesa fulva (Kieffer, 1919) larva. a) Antenna, b) Labrum, SIV A (black arrow) and premandibles (white arrows), c) Mentum, d) Ventromental plate, e) Mandible, arrow points to basal external seta with 2 branches at the base, f) Variation of basal external seta with several branches, g) Posterior portion of the larva.

Notes. Larval stages of O. fulva and O. ferringtoni (Sæther 1986) were revised by Liu et al. (2016). A major distinguishing character for the larvae is the shape of the ventromental plates. As compared to $O$. ferringtoni, the posterior margin of the ventromental plate of $O$. fulva is straight and practically parallel with the anterior margin (Liu et al. 2016). This contrasts Sæther's (1986) use of basal external setae characteristics to separate the two species. Additionally, Chinese specimens of $O$. fulva examined by Liu et al (2016) have a postmentum length of 180-200 $\mu \mathrm{m}$, extending the range of 131-158 $\mu \mathrm{m}$ presented by Sæther (1986); notably, the specimens discussed here have a postmentum length of 184.3-202.5 $\mu \mathrm{m}$. The seta interna of the mandible splits into 3 segments in our specimens, corresponding with characteristics of larval $O$. fulva nearctica Sæther, 1986; however, basal external setae of the mandible split into 2-8 branches as opposed to 12-23 branches for O. fulva nearctica reported by Liu et al. (2016).

Study sites. Bowmanville Creek, Bowmanville, Ontario; 435 54'22.90” N $78^{\circ} 41^{\prime} 12.8^{\prime \prime} \mathrm{W}$.

Ecology and habitats. Larvae inhabit shallow pools of rivers and streams, especially cold-water streams. This species is univoltine in its emergence phenology (Phillips et al. 2013).

Nearctic distribution: Canada (Ontario, Saskatchewan, Yukon Territory?); USA (Florida, Georgia, Illinois, Maine, Michigan, Minnesota, Mississippi, Montana, New Mexico, North Carolina, Pennsylvania, South Carolina, Wisconsin).

Notes: According to Phillips et al. (2013), there are debates regarding the occurrence of this species in Canada. The CNC collected specimens by D.R. Oliver in 1990 and record O. fulva from Frankford, Kintor, and Trout creeks in southern Ontario. Additionally, a single specimen was collected in 1976 by K. Dance near Waterloo, Ontario (Phillips et al. 2013). Report of the species from Yukon Territory is also not confirmed, although, Philips et al. (2013) report the species from this territory. Finding this species in Bowmanville Creek confirms the species' occurrence in Ontario and extends its range from southern to more central regions of the province. The species has also a Palearctic distribution, as it is widespread in Europe and has been reported in Xinjiang Uygur Autonomous Region of the Palearctic China (Liu et al. 2016).

\section{Rheosmittia spinicornis (Brundin, 1956)}

Pharate male (n=3). Fig. 2a-b.

Diagnosis. Antenna with 11 flagellomeres, $A R=0.47$. Thorax with prominent scutal tubercle (Fig. 2a). Inferior volsella digitiform and directed posteriorly (Fig. 2b).

Pupa (n=3). Fig. 2c, d. 

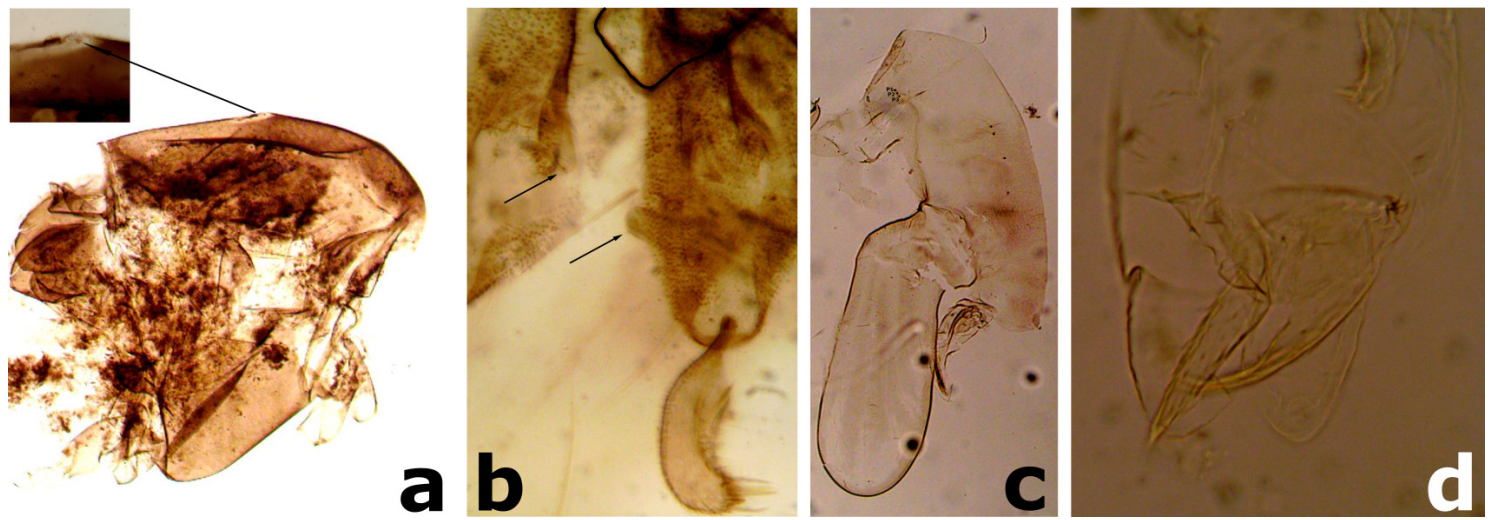

Figure 2. Rheosmittia spinicornis (Brundin, 1956) pharate male a-b, pupa c-d. a) Thorax, arrow indicates the location of scutal tubercle, b) Hypopygium, arrows indicate the inferior volsella, c) Cephalothorax, d) Anal lobes and genital sacs.

Description. Exuviae hyaline (Fig. 2c). Frontal setae absent. Precorneal seta 1-3 Ls =43.3, 51.0, $33.1 \mu \mathrm{m}$ long. Dorsocentral setae about 38.8-47.8 $\mu \mathrm{m}$ long. Anal lobe and genital sac (Fig. 2d).

Notes. A detailed description of species is given by Cranston and Sæther (1986).

Study sites. Bowmanville Creek, Bowmanville, Ontario; $43^{\circ} 54^{\prime} 22.90^{\prime \prime} \mathrm{N} 78^{\circ} 41^{\prime} 12.8^{\prime \prime}$ W. Lynde Creek, Whitby, Ontario; $43^{\circ} 54^{\prime} 42.27^{\prime \prime} \mathrm{N} 78^{\circ} 57^{\prime} 52.4$ ” W.

Ecology and habitats. Larvae of Rheosmittia are psammophile (Cranston and Sæther 1986).

Nearctic distribution: Canada (British Colombia, Northwest Territories, $1^{\text {st }}$ record Ontario, Saskatchewan, Yukon Territory).

Notes. Originally, this species was reported only from the Palearctic region (Ashe and O'Connor 2012); however, according to entries in the Barcode of Life Data Systems (Ratnasingham and Hebert 2007), this species also occurs in British Columbia, Northwest Territories, Saskatchewan and Yukon Territory. Considering our new record in Ontario, this species is probably widespread across the northern, western and central region of Canada.

\section{Sublettea coffmani (Roback, 1975)}

Pupa (n=2). Figs. 3a-e.

Description. Thoracic horn with long apical filaments (Fig. 3a). Robust patches of spines present on segments II-V (Fig. 3b), spine patches on segment IV and V with longer lateral spines (Fig. 3c). Paired spine patches are located in the anterior corners of the ventral intersegmental membrane of sternite VIII. (Fig. 3d). Anal lobe and genital sac as in Fig. 3e; anal lobe with robust patches of spines and long setae (Fig. 3e).

Notes. A detailed description of this species is given by Roback (1975). This is the only species of Sublettea described from the Nearctic.

Study sites. Lynde Creek, Whitby, Ontario; $43^{\circ} 54^{\prime} 42.27^{\prime \prime}$ N 78 57' 52.4” W.

Ecology and habitats. Larvae of Sublettea inhabit lotic habitats with a preference for cool, clear and fast flowing streams (Ashe and O'Connor 1994). Larvae of S. coffmani construct soft, non-transportable cases of fine sediments, which they attach to stream substrates (Roback 1975).

Nearctic distribution: Canada (New Brunswick, $1^{\text {st }}$ record Ontario); USA (Alabama, Georgia, Kentucky, Mississippi, North Carolina, Pennsylvania, South Carolina, Tennessee, Maryland, Virginia, and West Virginia).

\section{Acknowledgments}

We are grateful to the Central Lake Ontario Conservation staff especially Dan Moore for providing us with the specimens for this paper. 

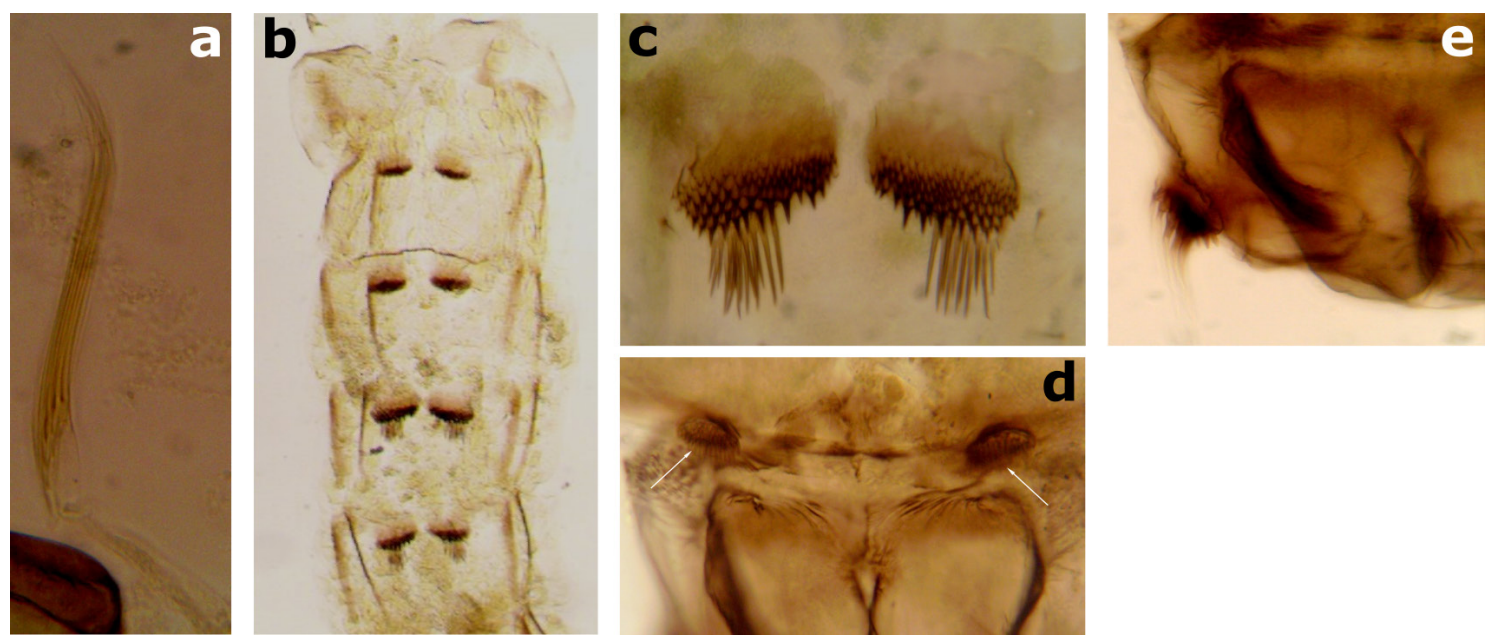

Figure 3. Sublettea coffmani (Roback, 1975) pupa. a) Thoracic horn, b) Abdominal tergite I-V, c) Spine patches on segment IV, d) Spine patches on ventral side of sternite VIII (arrows), e) Anal lobe and genital sac.

\section{References}

Ashe, P. and O'Connor, J.P. 2012. A world catalogue of Chironomidae (Diptera) Part 2 Orthocladiinae, Sections $A$ and B. Irish Biogeographical Society and National Museum of Ireland, Dublin, Dublin, Ireland, $968 \mathrm{p}$.

Ashe, P.D. and O’Connor, J.P. 1995. A new species of Sublettea Roback from Sulawesi. In Cranston, P.S. (Ed.) Chironomids, from gene to ecosystem. CSIRO, Australia. pp. 431-436.

Central Lake Ontario Conservation. 2012. Lynde Creek Watershed Plan. Available online at: http://www. cloca.com/lwc/manageplans_watershed.php

Central Lake Ontario Conservation. 2013. Bowmanville/Soper Creek Watershed Plan. Available online at: http://www.cloca.com/lwc/manageplans watershed.php

Cranston, P. S., and Sæther, O. A. 1986. Rheosmittia (Diptera: Chironomidae): a generic validation and revision of the western Palaerctic species. - Journal of Natural History 20(1): 31-51. DOI: http://dx.doi. $\underline{\operatorname{org} / 10.1080 / 00222938600770041}$

Epler, J.H. 2001. Identification manual for the larval Chironomidae (Diptera) of North and South Carolina. A guide to the taxonomy of the midges of the southeastern United States including Florida, Special Publication SJ2001-SP13. North Carolina Department of Environment and Natural Resources Division of Water Quality and St. Johns River Water Management District, Palatka, FL, 526p.

Jones, C., Somers, K.M., Craig, B. and. Reynoldson T.B. 2007. Ontario Benthos Biomonitoring Network: Protocol Manual, 109 p. Queen's Printer for Ontario, Available online at: http://desc.ca/sites/default/ files/OBBN2007finalapril18c.pdf

Liu, W., Ferrington, L. C., and Wang, X. 2016. First record of Odontomesa Pagast from China, with description of the immature stages of $O$. ferringtoni Sæther (Diptera, Chironomidae, Prodiamesinae). Zootaxa 4132 (1): 135-142. DOI: http://doi.org/10.11646/zootaxa.4132.1.12

Phillips, I. D., Parker, D., Hoemsen, B. M., Bell, A. J., and Chivers, D. P. 2013. Biological notes and range expansion of the non-biting midge Odontomesa fulva (Kieffer) (Diptera: Chironomidae). - Western North American Naturalist 73(2): 244-247. DOI: https://doi.org/10.3398/064.073.0216

Pinder, L. C. V. 1978. A key to adult males of the British Chironomidae (Diptera), Vol.. 1, The key; Vol. 2, Illustrations of the hypopygia. - Freshwater Biological Association Scientific Publication 37: 1-169.

Ratnasingham, S., and Hebert, P. D. 2007. BOLD: The Barcode of Life Data System (http://www. barcodinglife. org). - Molecular Ecology Resources 7(3): 355-364. DOI: http://dx.doi.org/10.1111/j.14718286.2007.01678.x 
Roback, S. S. 1975. A new subgenus and species of the genus Tanytarsus (Chironomidae: Chironominae: Tanytarsini). - Proceedings of the Academy of Natural Sciences of Philadelphia 127: 71-80.

Sæther, O. A. 1986. A review of Odontomesa Pagast, 1947 (Diptera, Chironomidae, Prodiamesinae). Spixiana Supplement 11: 15-29.

Sæther, O. A. 1980. Glossary of chironomid morphology terminology (Diptera: Chironomidae). - Entomologica Scandinavica 14: 1-51.

Article submitted 2. November 2017, accepted by Alyssa M. Anderson 28. November 2017, published 18. December 2017. 